\title{
DETERMINATION OF VISCOSITY OF WILD MANGO (Irvingia gobonensis), HIBISCUS (Rosa sinensis) AND OKRO (Abelmoschus esculentus) AT DIFFERENT TEMPERATURES
}

\author{
I. E. Essien \\ Department of Physics, University of Uyo, Uyo, Nigeria \\ S. E. Etuk \\ Department of Physics, University of Uyo, Uyo, Nigeria \\ A. A. Essiett \\ Department of Physics, University of Uyo, Uyo, Nigeria \\ J. G. Atat \\ Department of Physics, University of Uyo, Uyo, Nigeria \\ E. E. Ekott \\ Department of Physics, University of Uyo, Uyo, Nigeria
}

Article DOI: https://doi.org/10.36713/epra3946

\begin{abstract}
Viscosity is an important factor in fluid transport. It is a quantity that influences flow properties of fluid and quite useful food product designs. This study is aim at determining the viscosity of selected plant based materials, Wild mango, Hibiscus and Okro and to obtain a viscosity temperature model necessary to predict viscosity of these materials at various temperature values. The viscosity of these materials were determined using the volume flow rate method at a temperature range between $299 k$ to $383 k$ and the viscosity temperature model obtained from an empirical relationship. Wild mango exhibited the highest value of coefficient of viscosity at all temperature range with values between $18.3 x$ $10^{-3} \mathrm{NSm}^{-2}$ to $5.45 \times 10^{-3} \mathrm{NSm}^{-2}$ while Hibiscus and Okro have values of coefficient of viscosity ranging between $6.69 x$ $10^{-3} \mathrm{NSm}^{-2}$ to $1.82 \times 10^{-3} \mathrm{NSm}^{-2}$ and $8.05 \times 10^{-3} \mathrm{NSm}^{-2}$ to $2.10 \times 10^{-3} \mathrm{NSm}^{-2}$ respectively. The coefficients of viscosity of these materials were found to decrease with increase in temperature. The viscosity temperature model obtained for wild mango, Hibiscus and Okro are $\mu_{w}=0.91 \times 10^{-3} T^{-5.39}, \mu_{H}=3.85 \times 10^{-3} T^{-4.56}$ and $\mu_{K}=15 \times 10^{-3} T^{-3.23}$ respectively
\end{abstract}

KEY WORDS: Viscosity, temperature, Wild mango, Hibiscus, Okro 


\section{INTRODUCTION}

Viscosity is a fundamental quantity that determines the flow properties of fluids. It is defined as a quantitative measure of fluid resistance to flow. It is an internal friction which resists the sliding fluid layers moving over each other [1]. The viscosity of liquids occurs primarily due to the cohesive forces existing between the molecules of the fluid. Highly viscous fluid will not pour or spread out easily as fluid with lesser viscosity. Knowledge of viscosity of materials is required in the design of food products because the resistance of food products to flow is critical to processing, pumping, filling and moulding of the food products. It also affects product properties such as mouth feel, pour ability, cling, emulsion stability and ease of swallowing $[2,3]$

. Several studies on the viscosity of vegetable oils and effect of temperature on it have been undertaken by different researchers $[4,5,6]$. Reports also exist on the study of viscosity of fruit juice. It has well been reported in literatures that temperature has a strong effect on the viscosity of fluid products where it found that viscosity decreases with increase in temperature and a viscosity- temperature relationship has been developed [7].

In this work the viscosity of some local plant materials that are viscous at aqueous state and effect of temperature variations on their viscosity are evaluated.

\section{MATERIALS}

The materials considered are Wild mango (Irvingia gobonensis), Hibiscus (Rosa sinensis) and Okro (Abelmoschus esculentus).

(i). Wild Mango (Irvingia gobonensis)

Wild mango is considered as a multipurpose fruit tree in India because it provides food, fuel, fiber and timber in the country [8]. This fruit contains seed known as the kernel with oil. The oil is highly nutritive and used for bakery, production of cosmetics, dikka fat, chocolate and soap [9]. In South- south Nigeria it is used as thickening agents in soup and stew and also as flavoring agent [10]. Wild mango is identified with many local names in African countries such as dika nut, egili (Igala, Nigeria), Oghi (Etsako, Nigeria), African mango [11] others are Mbukpap Uyo (Ibibio, Akwa Ibom State, Nigeria) and Ogbonor (Ibo speaking Nigerians) and bush mango (India). Irvingia gbonensis are commonly found in the tropical rain forest of Nigeria, Cameroon, Congo, Ivory Coast $[12,13]$. The wild mango are reported to appear in different colours, green, greenish yellow, Yellow, Brownish yellow and reddish yellow [14].

To extract the kernel the fruit is allowed to ferment and sundried after which the endocarp is cracked open and the kernel (cotyledons) are extracted and kept in a dry place. The nutritive value of the fruits, the kernel seed, physicochemical properties and aroma content of the Bush mango are reported in the literature $[9,10]$

(ii) Hibiscus (Rosa sinensis L.)

Hibiscus is an ornamental plant commonly planted in gardens and compound in Nigeria. It has dark red coloured flowers and green leaves [15]. It is reported that it has a high nutritive and medicinal values $[16$, 17]. In China it is reported that the dye is used for foods and liquors. In Akwa Ibom State, Nigeria, Hibiscus leaves are used as food, beverages, soup thickening agent, tea, spices, sauces and as medicine as also applied elsewhere [18]. The Hibiscus leaves are also use as mild laxative, expectorant, diuretic [19] the aqueous ethanolic extract of Rosa senensis aerial part is used in cure of constipation and diarrhea [15]

(iii). Okro (Abelmoschus esculentus)

Okro is one of the vegetables that are viscous in aqueous state. It is commonly found in the tropical region which includes Nigeria. Okro exhibits a gum like nature in its aqueous state and usually used in soup making. The gum-like nature of this food thickening material is as a result of the presence of a chemical substance known as glycan [20]. It is reported to be rich in energy, protein, niacin, ascorbic acid and vitamins [21]. It is also known to contain linoleic and oleic acids. The linoelic acid consists of two conjugated double bonds while oleic acid consist of a single double bond which are being affected by temperature $[22,23]$

\section{SAMPLE COLLECTION AND PREPARATION}

All the materials were purchased fresh from a local market in Uyo, Nigeria and stored in polythene bags. All foreign materials on the samples were removed by washing with distilled water. Each of these materials was grounded to form paste using electric blender and $100 \mathrm{~g}$ of these materials was mixed with $1000 \mathrm{ml}$ of distilled water, stirred to dissolve and form solution. The solution was filtered and smooth gel obtained for the experiment. Relative densities of the solution were measured using the specific gravity bottle according to [24]. The diameter of the capillary tube was measured with vernier calipers. The solutions used for the experiment was maintained at constant temperature at each time of measurement using Marriott tank. The 


\section{EPRA International Journal of Research and Development (IJRD) \\ Volume: 5 | Issue: 1 | January 2020 \\ - Peer Reviewed Journal}

starting temperature was $298 \mathrm{k}\left(25^{\circ} \mathrm{C}\right)$ and varied in steps of $20{ }^{\circ} \mathrm{C}$ to $358 \mathrm{k}\left(85^{\circ} \mathrm{C}\right)$. The viscosity of each of the materials was evaluated at these varying temperatures respectively. In the evaluation, two fundamental theories were employed in the evaluation.

\section{THEORITICAL BACKGROUND}

(i) The volume flow rate method (HazenPoiseulli's theory)

Suppose a solution of coefficient of viscosity $(\mu)$ flows steadily through a capillary tube of diameter (a) and length $(\mathrm{L})$ thus creating pressure $(\mathrm{P})$ at the pressure head $(\mathrm{H})$. The volume flow rate $\mathrm{Q}$ is given as [25]

$$
\begin{aligned}
Q & =\frac{\pi P a^{4}}{8 \mu L} \\
\text { Let } \quad P & =g \rho H
\end{aligned}
$$

Where $\rho$ is the density of the solution and $g$ is the acceleration due to gravity

$$
\begin{gathered}
Q=\frac{\pi a^{4} g \rho H}{8 \mu L} \\
\text { or } \quad \mu=\frac{\pi g \rho a^{4}}{8 L} \frac{\Delta H}{\Delta Q} \\
R=\frac{8 \mu L}{\pi a^{4}}
\end{gathered}
$$

$\mu$ is the coefficient of viscosity and R is known as the flow resistance of the solution

(ii) Viscosity- temperature modeling

The viscosity- temperature function is given as a power law [26]

$$
\mu=a T^{b}
$$

$\mathrm{T}$ is the absolute temperature. The constants $\mathrm{a}$ and $\mathrm{b}$ are obtained from a plot according to equation 7

$$
\ln \mu=\ln a+b \ln T
$$

\section{V.RESULTS AND DISCUSSION}

The determinations of the coefficient of viscosity of different materials are reported in literatures by many authors. This is because of its effect on the flow rate, absorption and drainage rate of materials and its consequences when applied in production procedures. The need to consider the effect of temperature on the viscosity of these materials is also paramount because heating of these materials could be necessary during production process. In this study, chemical composition of the materials were not analysed, however it is known that the viscous nature of these materials is due to the presence of a chemical substance known as glycan.

\section{(i) The Volume flow rate}

The volume flow rate $\left(\mathrm{Q} \mathrm{cm}^{3} / \mathrm{s}\right)$ at different pressure heads $(\mathrm{H} \mathrm{cm})$ were studied at a temperature of $333 \mathrm{k}$ $\left(60^{\circ} \mathrm{C}\right)$ for the three materials are results presented in Table 1.0. it was also observed that the flow times were different at the same temperature. Equally observed was that as the pressure heads increases, the flow rate of all the solutions also increases. Density of the materials were also considered in this study, as it is known to be an important factor which influences the absorption and drainage rate of materials [5]. The measured density of the studied material shows that wild mango (Irvingia gobonensis) has a density of $1.041 \times 10^{-3} \mathrm{Kg} / \mathrm{m}^{3}$ while Hibiscus and Okro recorded $0.996 \times 10^{-3} \mathrm{Kg} / \mathrm{m}^{3}$ and $0.972 \times 10^{-3} \mathrm{Kg} / \mathrm{m}^{3}$ respectively at a temperature of 298 $\mathrm{K}\left(23^{\circ} \mathrm{C}\right)$. It was observed that the density of these solutions were linearly dependent on temperature. However the variations in the densities of these materials at the various temperature considered in this study were minimal as the difference in the temperature range was small between $10^{\circ} \mathrm{C}(283 \mathrm{~K})$ to $27^{\circ} \mathrm{C}(290 \mathrm{~K})$. 
Table1. Volume flow rates for the investigated materials at temperature of $333 \mathrm{k}$

\begin{tabular}{|l|l|l|l|}
\hline & \multicolumn{3}{|c|}{ Q $\left(\mathrm{cm}^{3} / \mathrm{s}\right)$} \\
\hline $\mathrm{H}(\mathrm{cm})$ & $\begin{array}{l}\text { Wild mango } \\
(\mathrm{Qw})\end{array}$ & $\begin{array}{l}\text { Hibiscus } \\
(\mathrm{QH})\end{array}$ & $\begin{array}{l}\text { Okro } \\
(\mathrm{Qk})\end{array}$ \\
\hline 12.0 & 0.11 & 0.50 & 0.45 \\
\hline 13.0 & 0.14 & 0.62 & 0.52 \\
\hline 14.0 & 0.19 & 0.75 & 0.62 \\
\hline 15.0 & 0.23 & 0.84 & 0.70 \\
\hline 16.0 & 0.28 & 0.95 & 0.78 \\
\hline 17.0 & 0.35 & 1.50 & 0.87 \\
\hline Time $(\mathrm{sec})$ & 360.0 & 250.0 & 300.0 \\
\hline$\rho\left(\mathrm{g} / \mathrm{cm}^{3}\right)$ & 1.014 & 0.996 & 0.972 \\
\hline $\mathrm{L}(\mathrm{cm})$ & 47.60 & 47.60 & 47.60 \\
\hline
\end{tabular}

The above Table1.0 shows the volume flow rates of the different solutions with different densities at different

pressure heads, flow time, from same capillary tube length at same temperature of $333 \mathrm{k}\left(60^{\circ} \mathrm{C}\right)$.

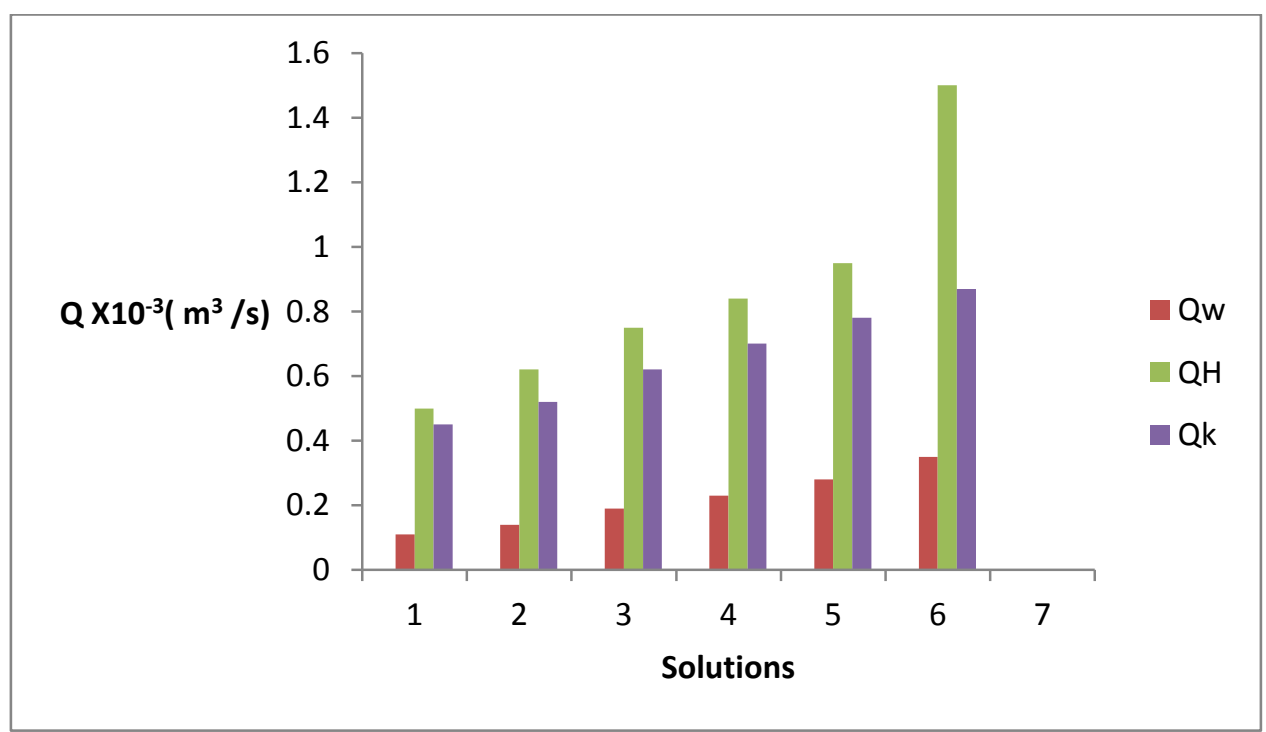

Fig. 1: Comparison of the volume flow rate of the investigated materials at 333k

The comparison of the volume flow rate for all the solutions are presented in Fig. 1 where it is seen that at all pressure heads hibiscus exhibited the highest

flow rate with wild mango being the least. Similarly the flow rate of these materials exhibited the same flow rate at other temperature range. 


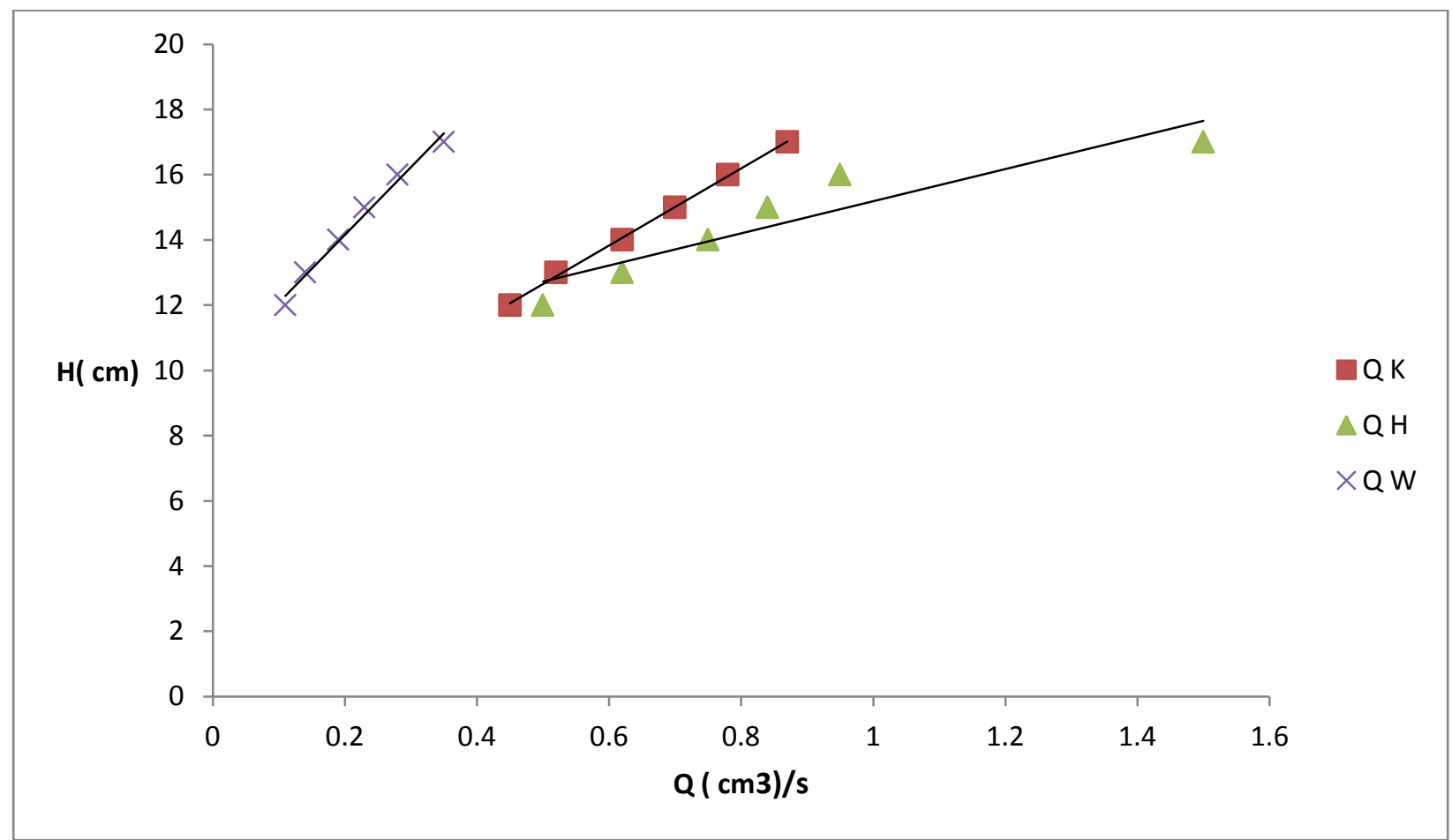

Fig. 2: Volume flow rate of the solutions at $333 \mathrm{k}$ at different pressure heads

Figure 2 shows the volume flow rate of the solutions at a temperature of $333 \mathrm{k}$ at certain pressure heads. The $\mathrm{Q}_{\mathrm{k}}, \mathrm{Q}_{\mathrm{H}}$ and $\mathrm{Q}_{\mathrm{w}}$ are the flow rates for okro, hibiscus and wild mango solutions respectively. From the regression of the lines in Fig. 2 above, the coefficient of viscosity of the viscous solution are determined by fitting the slope into equation 4 . Similar procedures for obtaining the viscosity were undertaken for the solutions at temperatures $299 \mathrm{k}, 306 \mathrm{k}$ and $359 \mathrm{k}$, $373 \mathrm{k}$ and $383 \mathrm{k}$ and results recorded in Table 2.0.

Table 2: Variation of viscosity with absolute temperature.

\begin{tabular}{|l|l|l|l|}
\hline \multicolumn{4}{|c|}{$\mu \times 10^{3} \mathrm{NSm}^{-2}$} \\
\hline Temp K & Wild mango & Hibiscus & Okro \\
\hline 299 & 18.13 & 6.69 & 8.05 \\
\hline 306 & 13.19 & 5.18 & 6.98 \\
\hline 333 & 8.99 & 3.52 & 3.98 \\
\hline 359 & 7.52 & 2.35 & 2.75 \\
\hline 373 & 6.60 & 2.01 & 2.43 \\
\hline 383 & 5.45 & 1.82 & 2.10 \\
\hline
\end{tabular}

\section{Viscosity - temperature modeling}

Analysis of the variation of coefficient of viscosity with absolute temperature (Table 2) shows that viscosity of these solutions decreases with increase in temperature similar to results of other studies. Wild mango (Irvingia gobonensis) was found to have the highest value of coefficient of viscosity at all temperature range between $18.3 \times 10^{-3} \mathrm{NSm}^{-2}$ to $5.45 \times 10^{-3} \mathrm{NSm}^{-2}$ than others, this could be due to the fact that wild mango was denser than hibiscus and Okra. Hibiscus (Rosa sinensis) and Okro (Abelmoschus esculentus) had value of coefficient of viscosity of $6.69 \times 10^{-3} \mathrm{NSm}^{-2}$ to $1.82 \times 10^{-3} \mathrm{NSm}^{-2}$ and $8.05 \times 10^{-3} \mathrm{NSm}^{-2}$ to $2.10 \times 10^{-3} \mathrm{NSm}^{-2}$ respectively. Although Okro was denser than hibiscus at $299 \mathrm{~K}$ however, it was observed that at high temperature the hibiscus solution become less viscous than Okro. It is reported in the literature that viscosity of oil and fatty acids which are some contents of the studied materials governs the absorption and drainage rate of these materials. Consequently the higher the viscosity of the material the slower the absorption and drainage rate of the material [27]. It is important that the influence of 


\section{EPRA International Journal of Research and Development (IJRD) \\ Volume: 5 | Issue: 1 | January 2020 \\ - Peer Reviewed Journal}

temperature on the viscosity of materials be evaluated at different temperatures values to give valuable information on the effect of temperature variation on the flow rate of these materials and could guide the manufactures of medicine and other products that utilizes these materials. Viscosity-temperature correlations can give an understanding of the flow behavior of these materials at different temperatures. The viscosity temperature relationship is shown in Fig. 3 and the models for the calculation of viscosity values at variable temperatures is developed using equation 7 while the constants $\mathrm{a}$ and $\mathrm{b}$ are obtained through a plot of equation 7 as shown in Fig. 4

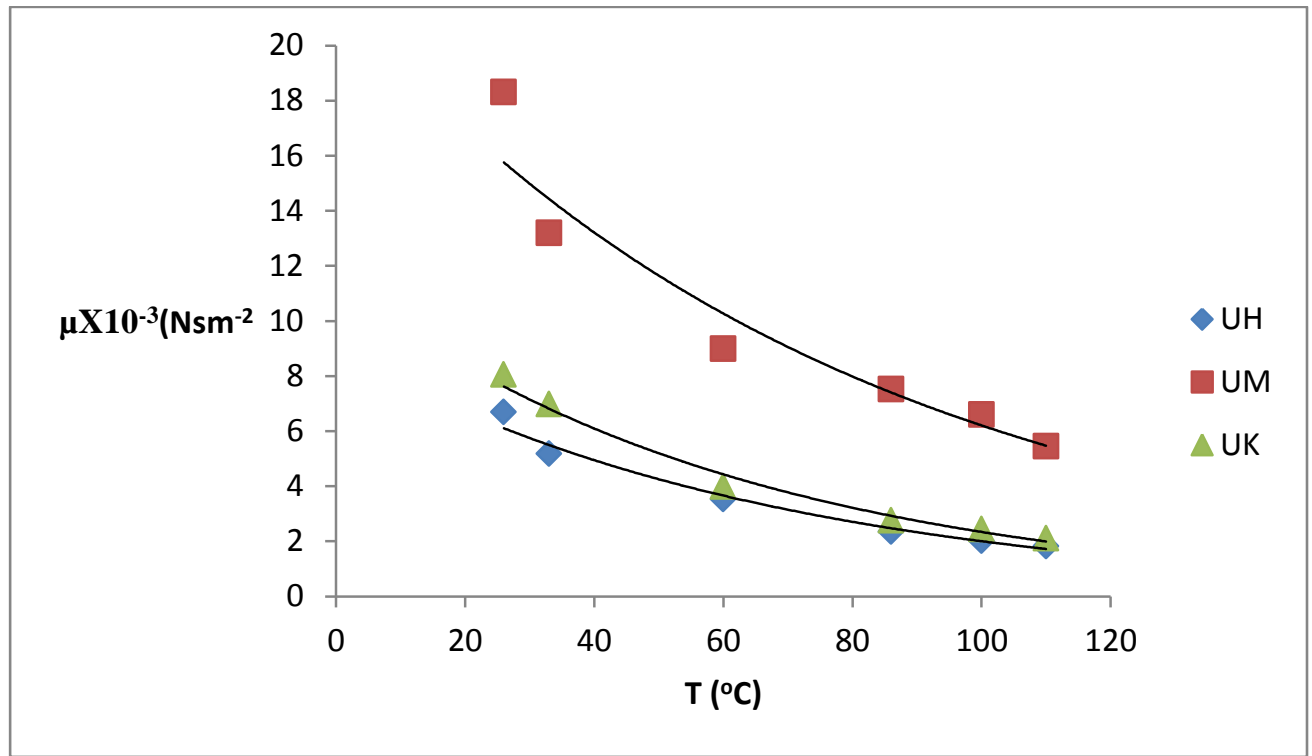

Fig. 3: The coefficient of viscosity of investigated materials as a function of temperature.

The linear plot of Fig. 3 to obtain the constants in equation 7 is presented in Fig. 4

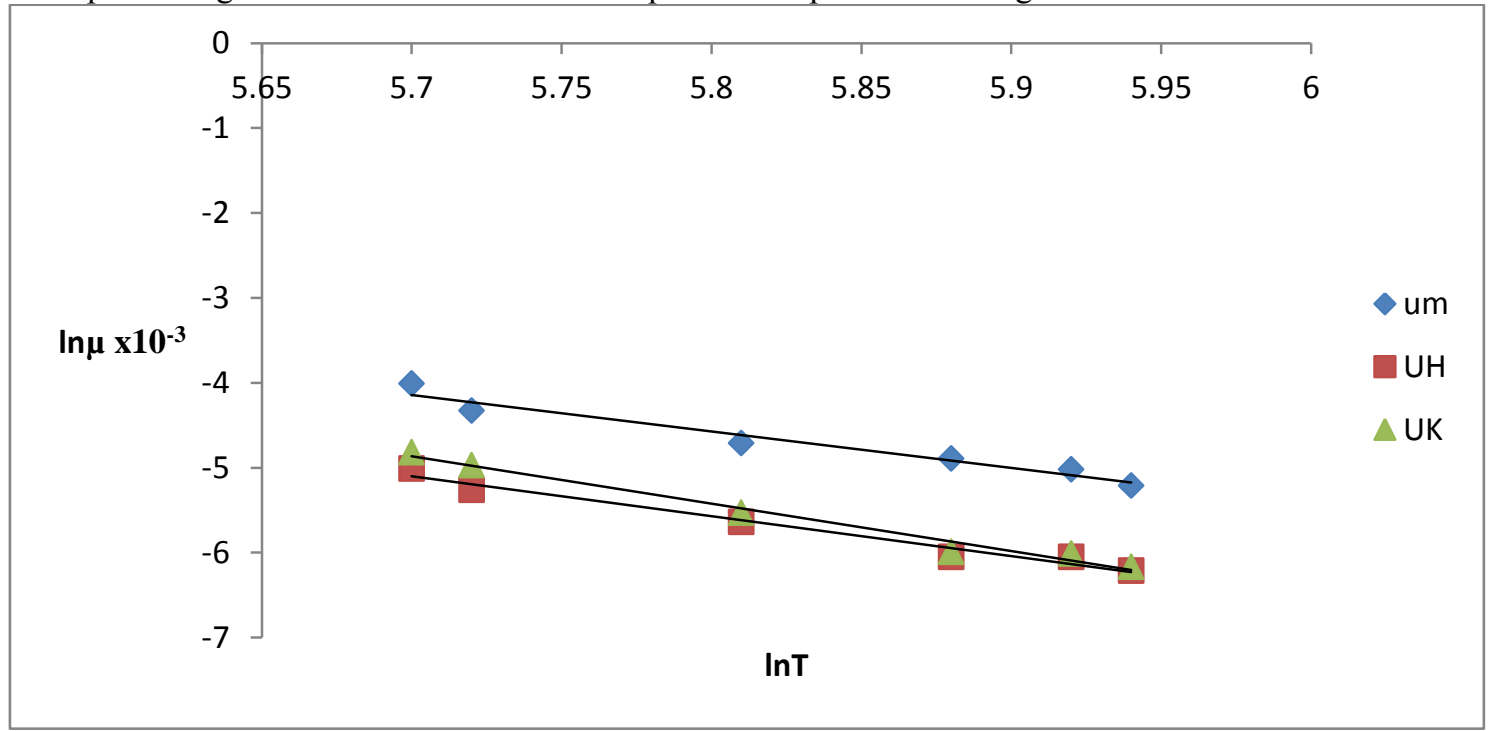

Fig. 4: The relationship of the dynamic viscosity and elevated temperatures

The constants $\mathrm{a}$ and $\mathrm{b}$ are obtained from the regression analysis of the line of best fits in Fig. 4 and presented in Table 3 
Table 3: Calculated values of constants $a$ and $b$ in equation 6

\begin{tabular}{|l|l|l|}
\hline Materials & $a \times 10^{-3}\left(\mathrm{Nsm}^{-2}\right)$ & $\mathrm{b}\left(\mathrm{Nsm}^{-2} \mathrm{~K}^{-1}\right)$ \\
\hline Wild mango & 0.91 & -5.39 \\
\hline Hibiscus & 3.85 & -4.56 \\
\hline Okro & 15.0 & -3.23 \\
\hline
\end{tabular}

To predict the viscosities of these biodiesels at various temperatures, the constants a and $\mathrm{b}$ are fitted into equation 6 to obtain equations 8,9 and 10 .

$$
\begin{gathered}
\mu_{w}=0.91 \times 10^{-3} T^{-5.39} \\
\mu_{H}=3.85 \times 10^{-3} T^{-4.56} \\
\mu_{K}=15 \times 10^{-3} T^{-3.23}
\end{gathered}
$$

8

Where $\mu_{W}, \mu_{H}, \mu_{K}$ are coefficient of viscosity of wild mango, Hibiscus and Okro respectively.

\section{VI.CONCLUSIONAND RECOMMENDATION}

Viscosity is seen to be affected by elevated temperature in a such a way that as the temperature of the materials rises, their viscous level decreases as corroborated by reports of various studies of other materials like vegetable oils, non-edible oils and oils used in biodiesel production.

The mathematical models developed can be used in predicting the variation of viscosity with elevated temperature, especially when these materials are considered for production of medicine and other food products.

\section{ACKNOWLEDGMENTS}

We would like to thank the technologists in the Department of Physics, University of Uyo for assisting in the running of these experiments and the staff of the Department of Forestry, University of Uyo, for identifying the research materials.

\section{REFERENCES}

1. Franco, $Z$ and Nguyen, $Q$ (2011). Flow Properties of Vegetable Oil Diesel Fuel Blends. Fuel, 90: 838843

2. Kuntz, L. A. Food Product Design, Weeks Publishing Co. North Brook ppl-6

3. Burubai, $W$ and Amber, $B$.(2013). Effect of Oven Drying on the Viscosity of Okro (Abelmoschus Esculentus). Journal of Food Processing and Technology, 4(12): 1-4

4. Fasina, O. O and Colley, Z. (2008). Viscosity and specific heat of Vegetable Oils as a function of Temperature $35^{\circ} \mathrm{C}$ to $180^{\circ} \mathrm{C}$. International Journal of Food properties, 11(4): 738-746
5. Nouredni, H., Teoh, B. C., and Clements, D. L (1999). Viscosities of Vegetable oils and Fatty Acid. Journal of Am. Oil. Chem Soc, 69: 1189-1191.

6. Igwe, I. O.(2004). The Effect of Temperature on the Viscosity of Vegetable Oils in Solution. Industrial Crops and Products, 19(2): 185-190.

7. Abdullaga, I., Abdukagatoov, A. and Azizo, N (2007). Viscosity of tangerine and lemon Juices as a function of Temperature and Concentration. International Journal of Food Sciences and Technology, 42: 804-818.

8. Singh, A. K. Bush Mango (Irvingia Gabonensis) (2007). New Potential Multipurpose Fruit Tree for India. Journal of Plant Genetic Resources. , 20(1); $31-37$

9. Omogbai, F. E.(1990). Lipid Composition of Tropical Seeds used in Nigerian Diet, Journal of the Science of Food and Agriculture, 50(2): 253-255

10. Van Buren (1970). The Biochemistry of Fruits and their Products. A C Hulme (ed). Academic Press. New York. 1970, PP 269-304

11. Onwuka, N. D (1983). Solvent Extraction and Characterization of Oils from the Breadfruit $(A B)$, African Mango (AB), and Oils Bean Seed $(O B)$. Progress in Food Engineering.. 175-179

12. Atangana, A. R, Ukafor V. Anegbeh, P, Asaah E. Tchoundjeu, Z, Fondoun, . M, Ndoumbe, $M$ and Leakey, R. R. B (2002). Domestication of Irvingia gobonenesis. The Selection of Multiple Traits for Potential Cultivars from Cameroon and Nigeria. Agro Forestry System. 55 (3): 221-229

13. Ladipo, D. O (1995). Management and Genetic Improvement of MTS in Humid Lowlands of West and Central Africa. In: ICRAF 1995 Annual Report. ICRAF. Nairobi, Kenya,

14. Ladipo D. O., Britwun S. P. K., Tchoundjeu, Z., Oni, $O$; and Leaky, R. R. B and Newton, A. C (1994); Tropical Trees: the Potential for 


\section{EPRA International Journal of Research and Development (IJRD) \\ Volume: 5 | Issue: 1 | January 2020 \\ - Peer Reviewed Journal}

Domestication and Rebuilding of Forestry Resources. HMSO. London

15. Kumar, A and Singh A. Review on Hibiscus (Rosa Sinensis ) (2012). International Journal of Research in Pharmaceutical and Biomedical Sciences. 3: 534

16. Trevisanato, S, Kim V. I. (2000). Tea and Health Nutrition Review,. $58: 1$

17. Filippo, F., Turchi, B; Gasperini, M; Torraco B., Giusti, M, Sagona S Feiicoli, A. Carri D (2014). Bee-gathered Pollen loads Suspension: Preliminary Assessment of Interaction with Microbial growth for a Potential employment as a natural Food additive. Journal of Microbiology, Biotechnology and Food Sciences, 3: 467

18. Ali, B. H., Wabel, N. A and Blunden G. (2015). Phytochemical, Pharmacological and Toxicological aspects of Hibiscus Sabdariffa L. A Review. A Phyto- therapy Research. 19: 369

19. Baranova, V. S., Rusina, I. F, Guseva D. A., Prozorovskaia, N. N., Ipatova, O. M., Kasaikina $O$. T.(2011). The antiradical Activity of Plants Extracts and Healthful Preventive combination of these Extracts with the Phospho-lipid Complex. Biomeditsinskaia Khimila. 58:712

20. Adetuyi, F. O., Osagie, A. U., Adekunle, A. T (2011). Nutrients, antinutrient, mineral and zinc bioavailability of Okro (Abelmoschus Esculentus L) Moench Variety. American Journal of Food Nutrition, 1: 49-54

21. Owoye, S.(1990). Chemical Properties of Okro . Journal of Tropical Fruits, 3: 100-104

22. Calisir, S., Ozcan M., Haciseferogullari H, Ugur Y. $M$ (2005). A study on some Physicochemical Properties of Turkey Okro (Hibiscus esculenta L.) seed. Journal of Food Engineering, 68: 73-78

23. Rubalya, V. S., Neelamegam, $P$ and Gayathri, K.(2009) A Study of anti oxidant Stability in Edible Oils using Rheological Parameter and in-vitro analysis. Asian Journal of Chemical, 21: 4325-4332

24. Etuk, S. E., Louis, E. A., and Samuel, D. E. (2002). Model for predicting proportion of diesel Fuel and Engine Oil Diesel adulterated SAE 40 Engine Oil sample. Global Journal of Pure and Applied Science, 8(4): 511- 514

25. Rajput, R. K. (2013). A Textbook of Fluid Mechanics and Hydraulic Machines, International Edition. S. Chand and Company Ltd. Ram Nagar, New Delhi, PP: 1-541

26. Sahasrabudhe, S. N, Martinez, V. R., Omeara, M and Farkas, B. E (2017). Density, Viscosity and Surface Tension of five Vegetables Oils at Elevated Temperature, Measurement and Modeling. International Journal of Food Properties, 20 (2): 1965-1981.

27. Ziaiifar, A. M., Achir, N., Courtois, F. Trezzani, I., Trystram, G. (2008). Review of mechanisms, Conditions and Factors Involved in the Oil Uptake
Phenomenon during Deep-Fat Frying Process. International Journal of Food Science and Technology, 43(8), 1410-1423 